Article

\title{
Antibacterial Activity of AI-Hemocidin 2, a Novel N-Terminal Peptide of Hemoglobin Purified from Arca inflata
}

\author{
Chunlei Li ${ }^{1,+}$, Jianhua Zhu ${ }^{1,+}$, Yanqing Wang ${ }^{2,+}$, Yuyan Chen ${ }^{1}$, Liyan Song ${ }^{3}$, Weiming Zheng ${ }^{3}$, \\ Jingjing $\mathrm{Li}^{3}$ and Rongmin $\mathrm{Yu}^{1,3, *}$ \\ 1 Biotechnological Institute of Chinese Materia Medica, Jinan University, Guangzhou 510632, China; \\ 1c1992@126.com (C.L.); tzhujh@jnu.edu.cn (J.Z.); 13533055513@163.com (Y.C.) \\ 2 National Engineering Research Center of Microsphere Technology for Controlled-Release Drug Delivery, \\ Zhuhai 519090, China; wangyanqing@livzon.cn \\ 3 Department of Pharmacology, Jinan University, Guangzhou 510632, China; tsly@jnu.edu.cn (L.S.); \\ miguelcheng170629@gmail.com (W.Z.); 13422016695@126.com (J.L.) \\ * Correspondence: tyrm@jnu.edu.cn; Tel.: +86-20-8522-0386; Fax: +86-20-8522-4766 \\ + These authors contributed equally to this work.
}

Received: 23 April 2017; Accepted: 27 June 2017; Published: 29 June 2017

\begin{abstract}
The continued emergence of antibiotic resistant bacteria in recent years is of great concern. The search for new classes of antibacterial agents has expanded to non-traditional sources such as shellfish. An antibacterial subunit of hemoglobin (Hb-I) was purified from the mantle of Arca inflata by phosphate extraction and ion exchange chromatography. A novel antibacterial peptide, AI-hemocidin 2, derived from $\mathrm{Hb}-\mathrm{I}$, was discovered using bioinformatics analysis. It displayed antibacterial activity across a broad spectrum of microorganisms, including several Gram-positive and Gram-negative bacteria, with minimal inhibitory concentration (MIC) values ranging from 37.5 to $300 \mu \mathrm{g} / \mathrm{mL}$, and it exhibited minimal hemolytic or cytotoxic activities. The antibacterial activity of AI-hemocidin 2 was thermostable $\left(25-100{ }^{\circ} \mathrm{C}\right)$ and $\mathrm{pH}$ resistant $(\mathrm{pH} 3-10)$. The cellular integrity was determined by flow cytometry. AI-hemocidin 2 was capable of permeating the cellular membrane. Changes in the cell morphology were observed with a scanning electron microscope. Circular dichroism spectra suggested that AI-hemocidin 2 formed an $\alpha$-helix structure in the membrane mimetic environment. The results indicated that the anti-bacterial mechanism for AI-hemocidin 2 occurred through disrupting the cell membrane. AI-hemocidin 2 might be a potential candidate for tackling antibiotic resistant bacteria.
\end{abstract}

Keywords: Arca inflata; peptide; hemoglobin; purification; structural elucidation; antibacterial activity

\section{Introduction}

The emergence and rapid spread of bacterial infections caused by antibiotic resistant strains has led to a health crisis in recent years [1-6]. The threat of drug-resistant bacterial infections has been attributed to the abuse and misuse of antibiotics as well as a lack of development of new antibacterial agents $[1,3,5,6]$. A recent investigation demonstrated that premature deaths caused by antibiotic resistant bacteria will rise to 1,000,000 lives per year and cost the global economy $\$ 100$ trillion by 2050 [7]. The urgent need for new types of antibacterial agents has led to innovative multidisciplinary research.

Antimicrobial peptides (AMPs) are produced by hosts as part of the innate immune response and constitute the first line of defense against invading pathogenic microbes [8]. AMPs typically comprise 10-50 amino acids, including basic residues such as arginine or lysine, that possess a positive net 
charge and amphipathic secondary structure such as an $\alpha$-helix or $\beta$-sheet [9-11]. Based on these properties, AMPs target and perturb the microbial cytoplasmic membranes that typically present anionic surfaces via an ionic interaction. Some investigations have demonstrated that most AMPs permeabilize microbial cytoplasmic membranes. Although most AMPs affect the integrity of microbial membranes, it remains to be determined whether the microbial membrane is the only site of action or whether membrane permeabilization is always fatal. Some AMPs that do not extensively permeabilize microbial membranes might interact with intracellular components and thus affect microbe viability. The mechanism of action of AMPs remains to be fully elucidated [12]. Compared with antibiotics, AMPs have drawn increasing attention as novel antibacterial agents to combat bacterial invasion due to their special mechanisms of action, non-inducible bacterial resistance and lack of detrimental effects on humans [13]. AMPs derived from marine organisms are promising candidates for drug development and as nutritional food additives. By contrast with on-land compounds, marine peptides have diverse sequences, unique structures and prominent bioactivities as a result of particular adaptations to oceanic environments [14]. Many peptides and derivatives (such as mytilin, defensin, mytimycin and myticins) derived from shellfish have been reported to exhibit antimicrobial activity [15] and have potential applications in the healthcare and fishery industries $[16,17]$.

Hemoglobin, which is widely distributed among organisms, has previously been regarded to function exclusively as an endogenous respiratory protein. However, studies have shown that hemoglobin exerts inhibitory effects on bacteria and is a source of antibacterial peptides, in addition to its role as an oxygen carrier, and its involvement in transporting sulfide and regulating the acid-base balance [18]. Antibacterial peptide fragments derived from hemoglobin subunits (hemocidins) have been considered as important effectors of the innate immune response against pathogen infections [19]. Hemocidins in humans, bovine and channel catfish were found to possess potent antimicrobial activities against pathogenic bacteria [20-24]. P3, a novel hemoglobin-related peptide derived from bovine erythrocytes, exhibited significant antimicrobial activity [25]. In addition, Hb137-141, a peptide isolated from the enzyme digestion of bovine hemoglobin alpha-chain showed potent antibacterial activity against Escherichia coli, Salmonella enteritidis, Listeria innocua, Micrococcus luteus and Staphylococcus aureus [26]. Although studies on hemocidins have been performed in a wide range of species, they have been limited to vertebrates. In some invertebrates, such as arthropods and mollusks, hemolymph is analogous to the blood in vertebrates. There are three types of oxygen-transport proteins in the hemolymph of invertebrates: hemoglobin, hemocyanin and hemerythrin [27]. Among these, hemocyanins are regarded as the major, multifunctional proteins in invertebrate hemolymph, responsible for oxygen transport and contributing to innate immunity in resisting invasion by pathogenic microbes $[27,28]$. Recently, hemocyanin-derived antimicrobial peptides have been identified from abalone, a marine mollusk [28]. However, few studies have focused on the hemoglobins and hemocidins of invertebrates.

A. inflata is a special type of bivalve shellfish that contains hemoglobin. A. inflata, which belongs to the Arcidae family under the phylum Mollusca and the class Lamellibranchiata, is widely distributed in the western Pacific Ocean. It has been used as a nutritious food material around the world, and a traditional medicine for treating blood deficiency, epigastric pain and indigestion for centuries in China. A polypeptide from A. inflata with impressive antitumor activity was reported by our research group [29]. However, little attention has been devoted to antibacterial peptides in A. inflata. As a result of their lack of a specific immune system, invertebrates such as $A$. inflata rely on the innate immune response comprising hemocytes and humoral factors to resist invasion from pathogens in the environment [30]. Therefore, it may be possible to discover novel antibacterial agents in marine invertebrates such as $A$. inflata.

Enzymatic hydrolysis is a feasible method with which to discover potent antibacterial peptides. Peptides hydrolyzed by trypsin, preferably containing arginine and lysine, usually possess positive charges and exhibit antibacterial activity [31,32]. However, it is difficult to identify the bioactive peptides among the huge number of peptides produced by hydrolysis. In addition, the bioactive 
peptides may become inactive during the enzymatic hydrolysis process. Since bioactive peptides possessing similar domain and physiochemical parameters exhibit similar bioactivities, bioinformatic analysis is a rapid and convenient method for discovering novel bioactive peptide sequences. Hence, enzymatic hydrolysis simulation combined with bioinformatic analysis is an efficient and innovative approach to discover potential antibacterial agents.

The aim of this study was to purify and characterize antibacterial agents from A. inflata. A novel antibacterial peptide, AI-hemocidin 2, was discovered from A. inflata and the physicochemical and structural properties were determined. Moreover, the preliminary mechanism of antibacterial action of AI-hemocidin 2 was revealed.

\section{Results and Discussion}

\subsection{Purification of $\mathrm{Hb}-\mathrm{I}$}

Following an antibacterial assay, $\mathrm{Hb}$-I was purified from the mantles of $A$. inflata by ammonium sulfate precipitation and column chromatography. The results of the purification process are shown in Figure 1 and Table 1.
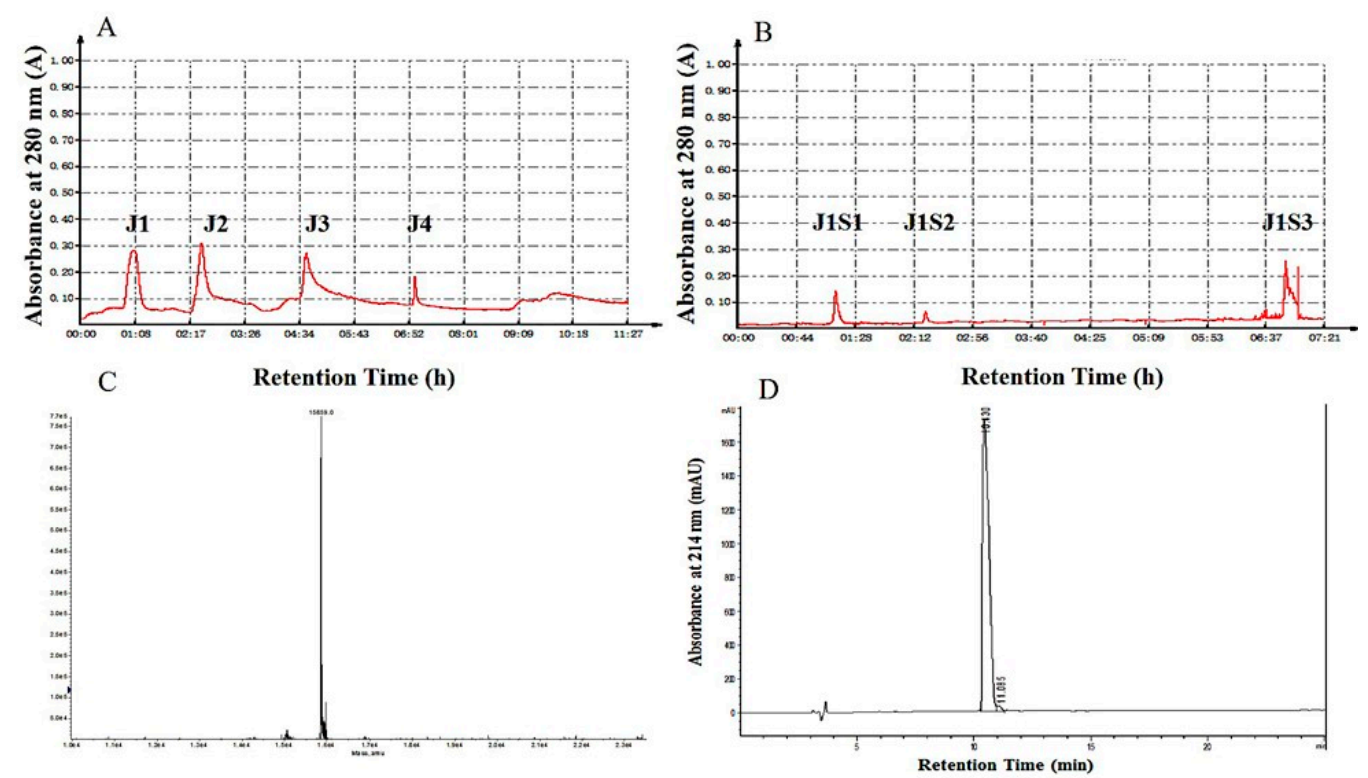

Figure 1. Purification of hemoglobin Hb-I: (A) separation of active fractions in the supernatant by DEAE Fast Flow anion exchange chromatography; (B) purification of active fraction J1S1 which contained $\mathrm{Hb}$-I obtained from (A) by SP Fast Flow anion exchange chromatography; (C) ESI-MS mass spectrum of $\mathrm{Hb}-\mathrm{I}$; and (D) the final purification of $\mathrm{Hb}-\mathrm{I}$.

Table 1. Antibacterial activity of each purified fraction against E. coli ATCC25922.

\begin{tabular}{lcccccccc}
\hline Fractions & J1 & J2 & J3 & J4 & J1S1 & J1S2 & J1S3 & Cipro \\
\hline IZ $(\mathrm{mm})$ & $10.18 \pm 0.24$ & $9.22 \pm 0.21$ & nd & nd & $16.19 \pm 0.62$ & nd & $6.74 \pm 0.18$ & $31.66 \pm 0.22$ \\
\hline IZ = Inhibition zone (mm). nd = not detected. Cipro = Ciprofloxacin. Sample amount: $20 \mu$ L. The concentration of \\
samples was $2.00 \mathrm{mg} / \mathrm{mL}$. Each assay was performed in triplicate, and the results are presented as the mean \pm SD.
\end{tabular}

The highest antimicrobial activity peak, J1S1, was obtained by a two-step purification procedure of ion-exchange chromatography (Figure 1A,B). J1S1 exhibited the highest antimicrobial activity against E. coli with inhibition zone diameters of $16.19 \pm 0.62 \mathrm{~mm}$. To evaluate the purity of fraction J1S1, tricine sodium dodecyl sulfate polyacrylamide gel electrophoresis (Tricine-SDS-PAGE), native polyacrylamide gel electrophoresis (Native-PAGE) and RP-HPLC were applied, as described in a previous study [33]. 
A single band in both Tricine-SDS-PAGE and Native-PAGE revealed that J1S1 was a pure polypeptide with an approximate molecular weight of $15 \mathrm{kDa}$ (Figure S1A,B). Furthermore, J1S1 was loaded onto a reversed-phase C18 column to confirm the purity. A single peak was found at $10.43 \mathrm{~min}$ (Figure 1D), highlighting the high purity of J1S1. Electrospray-ionization mass spectrometry (ESI-MS) analysis of purified J1S1 revealed that its accurate molecular weight was 15,859.0 Da (Figure 1C). Compared with organic solvent extraction, ammonium sulfate precipitation can be used to obtain more proteins and peptides with bioactivity. Many studies have used ammonium sulfate precipitation for antibacterial peptide isolation, including the purification of plantaricin 163 [34], plantaricin A-1 [35] and sakacin LSJ618 [36]. E. coli is one of the most common pathogenic bacteria and a frequent cause of nosocomial and community-acquired bacterial infections. In recent years, infections with E. coli have been increasingly reported, and the number of $E$. coli isolates found to be resistant to antibiotics, especially to cephalosporins and fluoroquinolones, has increased significantly during the last two decades [37]. The polypeptide fraction J1S1, purified from A. inflata, which is capable of inhibiting E. coli, is a promising candidate for the development of antibacterial agents.

\subsection{Identification of $\mathrm{Hb}-\mathrm{I}$}

J1S1 was subjected to amino acid sequence analysis by automated Edman degradation. The N-terminal amino acid sequence was determined to be PSVQGAAQQLTADVK (Figure S2). The results of BLAST searches showed only one match to the hemoglobin subunit I (Hb-I) of Scapharca broughtonii (BAM63323.1) with a high degree of similarity (93\%). With the polymerase chain reaction (PCR) technique, J1S1 that contained an open reading frame of 441 nucleotides was found to be identical to $\mathrm{Hb}-\mathrm{I}$ in A. inflata (GenBank: AB713934.1). By BLAST search, $\mathrm{Hb}-\mathrm{I}$ in A. inflata showed high similarity with the hemoglobin subunit I of Scapharca inaequivalvis, Arca subcrenata and Tegillarca granosa, but little similarity with the hemoglobin-related antibacterial peptides of vertebrates (Figure 2). Some studies have demonstrated clear antibacterial activity in the hemoglobin of vertebrates [19-27]. However, there has been little focus on the antibacterial effects of invertebrate hemoglobin and hemocidins. Compared with the hemoglobin subunit, hemocidins have stronger antibacterial activity and stability $[38,39]$ and therefore have the potential to be potent antibacterial agents.

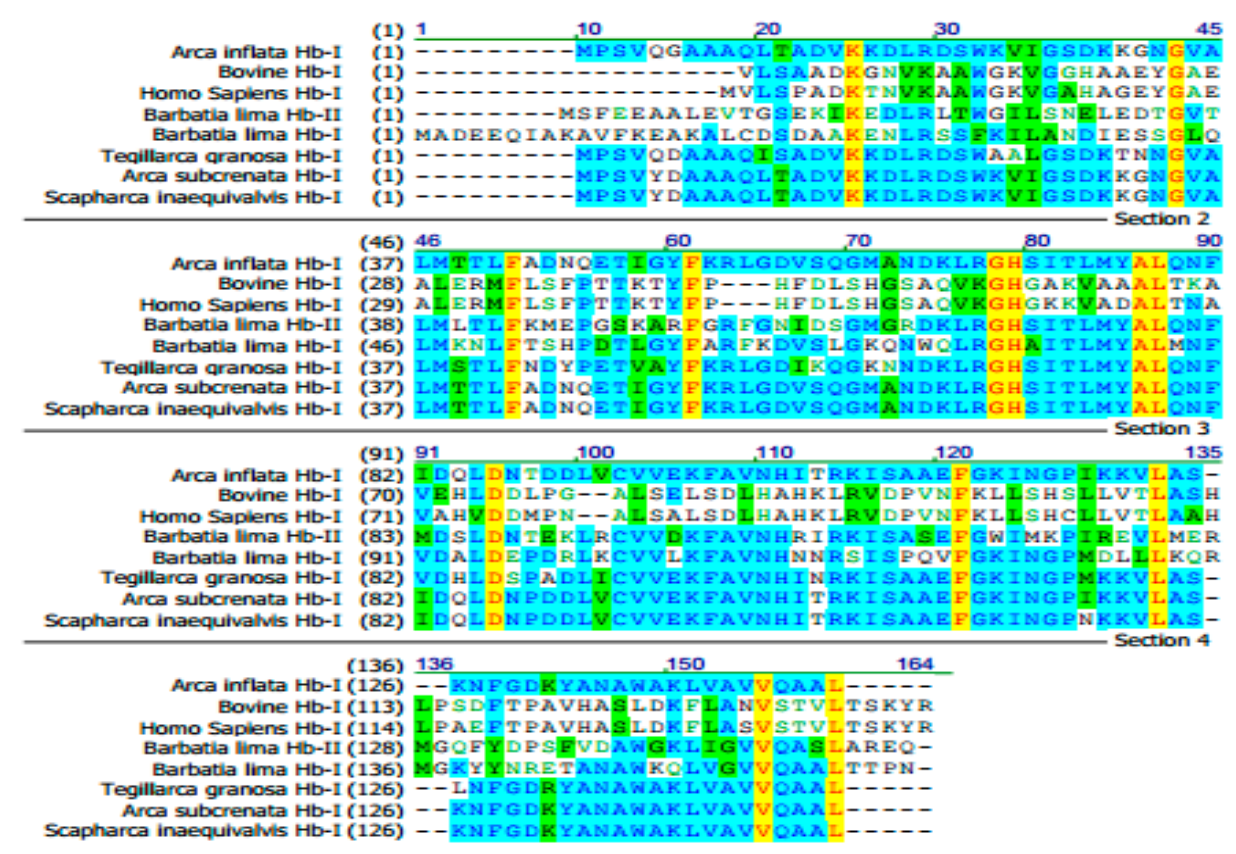

Figure 2. Sequence comparison of $\mathrm{Hb}$-I with the hemoglobin from other invertebrates. Identical amino acid residues are highlighted in yellow, and similar amino acid residues are highlighted in blue and green, respectively. 


\subsection{Bioinformatic Analysis and Antibacterial Function Screening}

Protein hydrolysis by enzymes is a feasible way to discover potent antibacterial peptides hidden in proteins. Peptides hydrolyzed by trypsin, preferably containing arginine and lysine, usually possess positive charges and exhibit antibacterial activity [31,32]. For example, indolicidin, which contained arginine or lysine at its C-terminus, displayed potent antibacterial activity [40]. Hydrolysis simulation combined with bioinformatic analysis is an efficient and innovative approach to discover potential antibacterial agents. Through trypsin hydrolysis simulation and bioinformatic analysis using the antimicrobial peptide database (APD), AI-hemocidins, including several peptide fragments with potential antibacterial function, were identified (Figure $3 \mathrm{~A}$ ).

A

A
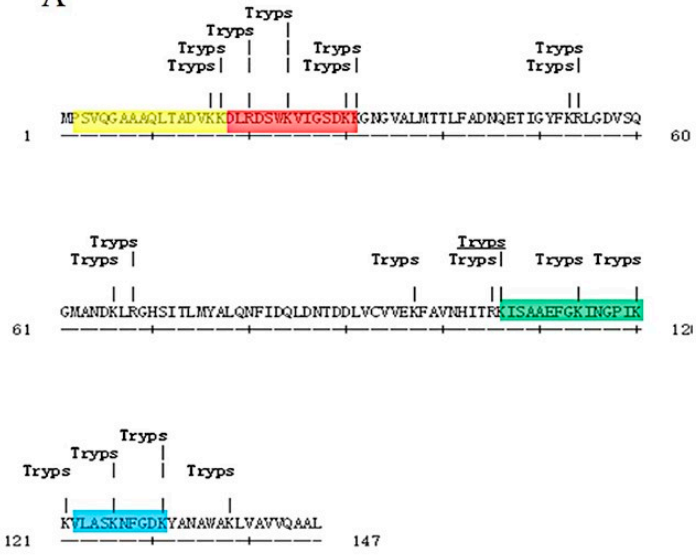

B
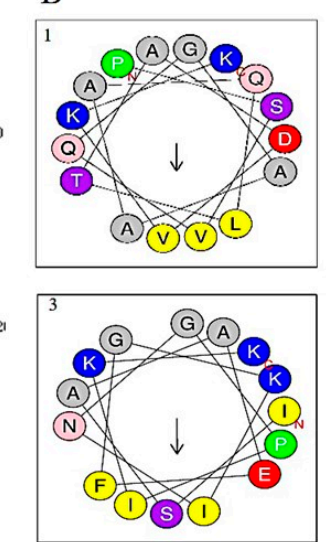
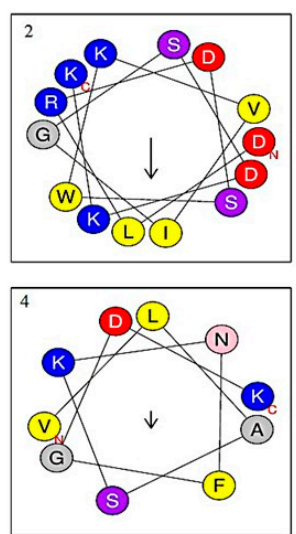

Figure 3. In silico analysis of $\mathrm{Hb}-\mathrm{I}$ : (A) Trypsin hydrolytic sites and peptide fragments aligned with APD; and (B) Schiffer and Edmundson helical wheel projection of AI-hemocidins. The hydrophobic residues are yellow, positively charged hydrophilic residues are blue, negatively charged hydrophilic residues are red, asparagine and glutamine are in pink color, small neutral residues are gray, and small polar residues are purple.

The sequences and physicochemical properties of AI-hemocidins are listed in Table 2. All peptides had a net positive charge and were proposed to be cationic peptides. The ratios of polar residues to nonpolar residues were approximately $50 \%$. Among them, AI-hemocidin 2 showed the highest ratio of polar residues to nonpolar residues $(71.43 \%)$, whereas AI-hemocidin 2 had the lowest hydrophobicity of 0.043. The predicted helix structures of the peptides are shown in Figure 3B. All peptides could form helixes, though only AI-hemocidins 2 was capable of forming a stable amphipathic structure that contained a hydrophobic side and a positively charged surface. Generally, antibacterial peptides possess several features indicative of their antibacterial activity [41,42]. One feature is their positive charge, and another feature is the presence of at least $50 \%$ of hydrophobic residues. The positive charge is conducive to an electrostatic interaction with the bacterial membrane, which is negatively charged [41]. The high ratio of hydrophobic residues is thought to contribute to disruption of the bacterial membrane. However, a more crucial feature of the peptides possessing antibacterial action is the formation of an ordered and stable amphipathic structure. The hydrophobic side of the structure is thought to enter into and disrupt the bacteria membrane, whereas the hydrophilic residues are considered to provide the opportunity to combine or adhere to the membrane surface [42]. Although AI-hemocidin 2 contained a high ratio of polar residues and low hydrophobicity, the amphipathic structure that formed between the hydrophobic side and a positively charged surface conferred antibacterial activity. 
Table 2. Sequences and physicochemical properties of AI-hemocidins.

\begin{tabular}{|c|c|c|c|c|c|c|c|}
\hline Peptide & Sequence & Length & pI & Mw & $\mathrm{NC}$ & $\mathbf{H}$ & PR/n \% \\
\hline 1 & PSVQGAAAQLTADVKK & 16 & 9.01 & 1583.81 & 1 & 0.196 & $8 / 50 \%$ \\
\hline 2 & DLRDSWKVIGSDKK & 14 & 8.50 & 1646.86 & 1 & 0.043 & $10 / 71.43 \%$ \\
\hline 3 & ISAAEFGKINGPIKK & 15 & 9.70 & 1572.87 & 2 & 0.285 & $8 / 53.33 \%$ \\
\hline 4 & VLASKNFGDK & 10 & 8.56 & 1078.23 & 1 & 0.163 & $6 / 60 \%$ \\
\hline
\end{tabular}

The antibacterial activities of $\mathrm{Hb}-\mathrm{I}$ and AI-hemocidins are shown in Table 3. Hb-I demonstrated adequate antibacterial activity against E. coli and S. aureus. Among the AI-hemocidins, AI-hemocidin 2 showed the high activity against the test strains, with the exception of Enterococcus faecalis. S. aureus exhibited the highest sensitivity to AI-hemocidin 2 with a MIC value of $37.5 \mu \mathrm{g} / \mathrm{mL}(22.77 \mu \mathrm{M})$. Compared with $\mathrm{Hb}$-I, the antibacterial effect of AI-hemocidin 2 was enhanced. Although $\mathrm{Hb}-\mathrm{I}$ was initially screened with E. coli, the antibacterial activity of AI-hemocidin 2 against several Gram-positive bacteria was observed. The results suggested that AI-hemocidin 2 was an antibacterial peptide with a broad antimicrobial spectrum. In addition, AI-hemocidin 1 displayed antibacterial activity selectively against Gram-negative bacteria Pseudomonas aeruginosa and E. coli with a MIC value of $75 \mu \mathrm{g} / \mathrm{mL}$ $(47.35 \mu \mathrm{M})$. Peptides derived from the erythrocytes of various living organisms have also been reported to exhibit antibacterial activity. Recently, hydrolyte fractions of bovine hemoglobin were reported to have antibacterial activity against bacteria invasion. A novel hemoglobin peptide, P3 derived from bovine erythrocytes, assumed an $\alpha$-helical conformation and exhibited modest antimicrobial activity in vitro. P3 killed bacteria rapidly by disrupting the bacterial cytoplasmic membrane and disturbing the intracellular calcium balance. Hemoglobin-related peptides are thereby becoming a new source of antibacterial agents that are capable of inhibiting pathogenic bacteria.

Table 3. Antibacterial activities of $\mathrm{Hb}-\mathrm{I}$ and AI-hemocidins.

\begin{tabular}{ccccccc}
\hline \multirow{2}{*}{ Bacteria } & \multicolumn{7}{c}{ MIC Value $(\boldsymbol{\mu M})$} \\
\cline { 2 - 7 } & $\mathbf{1}$ & $\mathbf{2}$ & $\mathbf{3}$ & $\mathbf{4}$ & Hb-I & Cipro \\
\hline E. coli ATCC 25922 & 47.35 & 45.54 & $>381.47$ & $>556.47$ & 75.66 & 24.14 \\
P. aeruginosa ATCC 27853 & 47.35 & 91.08 & 95.37 & $>556.47$ & $>100.88$ & 48.28 \\
P. aeruginosa clinical isolate & 47.35 & 91.08 & $>381.47$ & $>556.47$ & $>100.88$ & 48.28 \\
S. aureus ATCC 25923 & $>378.83$ & 22.77 & $>381.47$ & $>556.47$ & 75.66 & 24.14 \\
B. subtilis ATCC 6633 & $>378.83$ & 182.16 & $>381.47$ & 69.55 & $>100.88$ & 12.07 \\
B. subtilis ATCC 6633 & $>378.83$ & 182.16 & $>381.47$ & $>556.47$ & $>100.88$ & 12.07 \\
E. faecalis ATCC 29212 & $>378.83$ & $>364.33$ & $>381.47$ & $>556.47$ & $>100.88$ & 24.14 \\
\hline
\end{tabular}

Each assay was performed in triplicate. Cipro = Ciprofloxacin.

\subsection{Circular Dichroism Spectra and 3D Secondary Structure Prediction}

The secondary structure of AI-hemocidin 2 was investigated in different environments, including $10 \mathrm{mM}$ PBS solution and 50\% trifluoroethanol solution by circular dichroism (CD) spectroscopy [43]. As illustrated in Figure 4A, peptides displayed random coil conformations in PBS. However, the spectra of AI-hemocidin 2 featured an $\alpha$-helix conformation in the presence of $50 \%$ TFE, which was indicated by the presence of two negative dichroic bands at 208 and $222 \mathrm{~nm}$ [44]. The results of the CD spectrum in AI-hemocidin 2 were accordant to the secondary structure predicted by the helical wheel projection (Figure 3B). The modeling structure of AI-hemocidin 2 was proposed by Iterative Threading ASSEmbly Refinement (ITASSER) (Figure 4B). The structure of the antibacterial peptides allows for their insertion into bacterial membranes forming a voltage-dependent ion channel, thereafter altering the permeability of the bacterial cell, leading to disruption of cytoplasmic processes and target cell lysis [11]. The high level of $\alpha$-helix in AI-hemocidin 2 contributed to the sensitive antibacterial activity. 
A

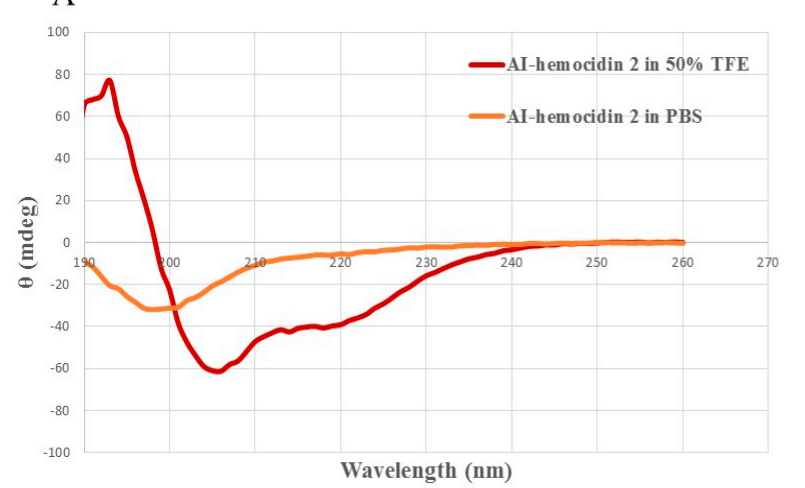

B

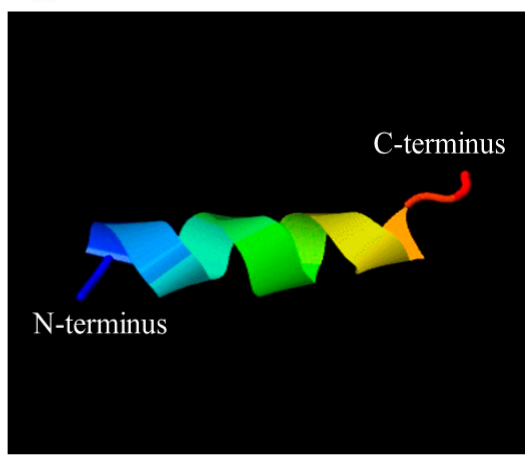

Figure 4. Secondary structure characterization of AI-hemocidin 2: (A) circular dichroism (CD) spectra of AI-hemocidin 2; and (B) 3D structural prediction of AI-hemocidin 2. The colors are meaningless and only used to perform the secondary structure in a nice-looking way.

\subsection{Assays for Hemolysis and Cytotoxicity}

AI-hemocidin 2 showed low hemolytic activity on murine red blood cells. The hemolysis of AI-hemocidin 2 reached a maximum of $10.27 \%$, even at a high concentration of $500 \mu \mathrm{g} / \mathrm{mL}$, which was 13 times higher than its MIC for S. aureus (Table 3). The HEK293 cell viability was approximately $88 \%$ after treatment with AI-hemocidin 2 at $250 \mu \mathrm{g} / \mathrm{mL}$. The half maximal inhibitory concentration of cell viability was larger than $1000 \mu \mathrm{g} / \mathrm{mL}$ (Table 4). The cytotoxic concentrations for HEK cells were higher than the MIC values. These results indicated that AI-hemocidin 2 displayed excellent bacteria selectivity (Table 4). Piscidin 1, a peptide purified from hybrid striped bass, possesses significant antibacterial action as well as cytotoxic activity [45]. The mechanism of action of its bactericidal and fungicidal effects was operated via targeting and disrupting the bacterial and fungal membranes $[46,47]$. However, the application of piscidin 1 has been limited on account of its cytotoxic effects. On the contrary, hemoglobin-derived peptides exhibit antibacterial activity with low cytotoxicity. SH $\beta$ AP and $\mathrm{P} 3$ were both hemoglobin-related antibacterial peptides derived from the liver of skipjack tuna and bovine, respectively [25,45]. SH $\beta$ AP and P3 both showed low hemolytic activity and cytotoxicity, although their mechanisms of antibacterial action were similar to Piscidin 1. The finding of low cytotoxicity and low hemolytic activity of AI-hemocidin 2 is comparable to $\mathrm{SH} \beta \mathrm{AP}$ and P3. The antimicrobial activity of AI-hemocidin 2 was not greatly affected by $\mathrm{pH}$ or heat treatment (Figure 5). As shown in Figure 5, compared with 0.01\% HAc ( $\mathrm{pH} 3)$ and sterile water (pH 7), the antibacterial activity of AI-hemocidin 2 was significantly decreased $(p<0.05)$ in $0.01 \% \mathrm{NaOH}(\mathrm{pH} 10)$, but still retained $60.76 \%$ antibacterial activity. The net charge of AI-hemocidin 2 (p.I. 8.5) was negative in $0.01 \% \mathrm{NaOH}(\mathrm{pH} 10)$ and this negatively charged state was not optimal for the association of AI-hemocidin 2 with the negatively charged bacterial membrane for antibacterial activity. The binding ability of AI-hemocidin 2 would have been decreased in $0.01 \% \mathrm{NaOH}(\mathrm{pH} 10)$, thus reducing the antibacterial activity. However, various amino acids display different isoelectric points and different charges in different solutions. AI-hemocidin 2 contained three aspartic acids at the hydrophilic side. The net charge of the hydrophilic portion with aspartic acids might be positive in $0.01 \% \mathrm{NaOH}(\mathrm{pH} 10)$, providing the possibility of an interaction between AI-hemocidin 2 and the negatively charged bacterial membrane. Therefore, AI-hemocidin 2 retained antibacterial activity even in $0.01 \% \mathrm{NaOH}(\mathrm{pH} 10)$ showing its potential as a candidate antibacterial agent. 
Table 4. Hemolysis activity and cytotoxicity of AI-hemocidin 2.

\begin{tabular}{cc}
\hline Sample & AI-Hemocidin-2 \\
\hline $\mathrm{MIC}^{\mathrm{a}}(\mu \mathrm{g} / \mathrm{mL})$ & $37.5-300$ \\
$\mathrm{HC}_{10} \mathrm{~b}_{(\mu \mathrm{g} / \mathrm{mL})}$ & $>500$ \\
$\mathrm{H}_{\max }$ & $10.27 \pm 0.42$ \\
Cell viability $(\%)$ at $250 \mu \mathrm{g} / \mathrm{mL}$ & $88.18 \pm 9.48$ \\
$\mathrm{IC}_{50} \mathrm{~d}(\mu \mathrm{g} / \mathrm{mL})$ & $>1000$ \\
SI value & $3.33-26.67$
\end{tabular}

Note: a Minimum inhibitory concentration of AI-hemocidin 2 against E. coli, P. aeruginosa, $P$. aeruginosa clinical isolate, S. aureus, S. epidermidis and B. subtilis. ${ }^{\mathrm{b}} \mathrm{HC}_{10}$ is the concentration of peptide causing $10 \%$ hemolysis on human erythrocytes. ${ }^{c} \mathrm{H}_{\max }$ is the percentage (\%) hemolysis at the highest tested peptide concentration (500 $\left.\mu \mathrm{g} / \mathrm{mL}\right)$. ${ }^{d} \mathrm{IC}_{50}$ is defined as the concentration at which $50 \%$ of growth is inhibited. e Selectivity index (in vitro): $\mathrm{IC}_{50}$ in HEK 293 cells $/$ MIC, IC $_{50}$ taken as a minimum, $1000 \mu \mathrm{g} / \mathrm{mL}$. Assays were performed in triplicate, and the results are presented as the mean $\pm \mathrm{SD}$.

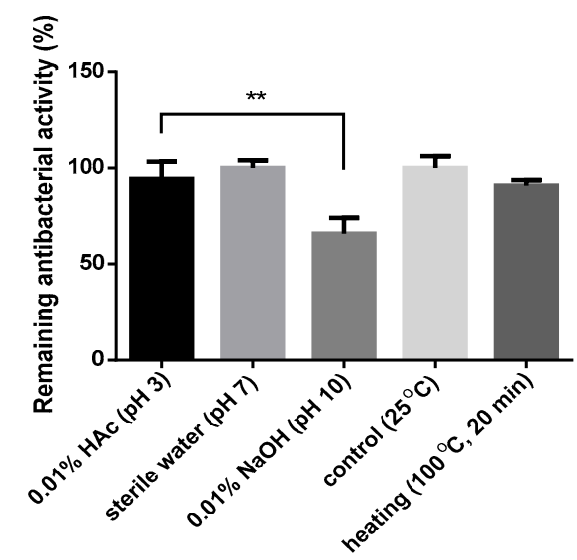

Figure 5. Stability of the antibacterial activity of AI-hemocidin 2 against $E$. coli during changes in $\mathrm{pH}$ and heat, ${ }^{* *} p<0.05$.

\subsection{Effects of AI-Hemocidin 2 on the Permeability of the Bacterial Membrane}

Increasing the permeability of the bacterial membrane is a possible mechanism by which peptides exert antibacterial function. Outer membrane permeabilization by AI-hemocidin 2 was assessed by an NPN uptake assay. Upon destabilization of the cellular membrane by AMPs, NPN inserted into the damaged membrane and emitted a strong fluorescence signal in the hydrophobic interior of the cell membrane [48]. As illustrated in Figure 6A, 45.54 $\mu \mathrm{M}$ (MIC) of AI-hemocidin 2 caused $57.2 \%$ NPN uptake by $E$. coli at $360 \mathrm{~s}$ after sample treatment, whereas $136.62 \mu \mathrm{M}$ $(3 \times$ MIC) of AI-hemocidin 2 induced higher NPN uptake $(81.66 \%)$. The results indicated that AI-hemocidin 2 was capable of permeabilizing the outer membrane in a dose-dependent manner. The permeabilization of the inner cytoplasmic membrane was measured by a $\beta$-galactosidase assay. O-nitrophenyl- $\beta$-D-galactopyranoside (ONPG) is hydrolyzed into o-nitrophenol in response to $\beta$-galactosidase released from the cytoplasm when the cytoplasmic membrane is permeable [49]. Therefore, ONPG was chosen as a probe to determine the permeability of the cytoplasmic membrane by spectrophotometry at $405 \mathrm{~nm}$. $\beta$-galactosidase leakage was observed from S. aureus (Figure 6B) and E. coli (Figure 6C) in the presence of AI-hemocidin 2 in a dose- and time-dependent manner. There was no change over time in the control cell medium. As shown in Figure 6B,C, the absorbance values with $3 \times$ MIC of AI-hemocidin 2 were not much higher than the values with $1 \times$ MIC of AI-hemocidin 2 . This may be because the $1 \times$ MIC concentration permeabilized the bacterial cytoplasmic membrane to a sufficient degree and that the $3 \times$ MIC concentration just accelerated this process. In addition, the absorbance values measured by a microplate reader (Figure 6B,C) showed little difference between the $1 \times$ MIC and $3 \times$ MIC treatments. As a result of its positive net charge and $\alpha$-helix structure, 
AI-hemocidin 2 possesses bacterial membrane permeability activity. AI-hemocidin 2 functions in a similar manner to bactenecin, permeabilizing the bacterial membrane in a rapid, reliable way [49]. The results of our experiments suggested that AI-hemocidin 2 could increase the permeability of the cytoplasmic membrane of pathogens, thereby exerting antibacterial activity.
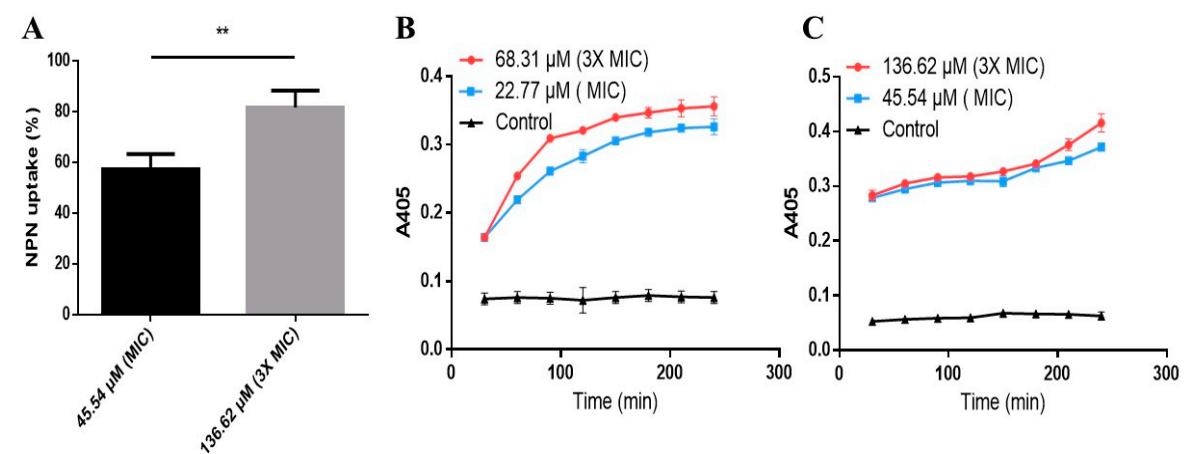

Figure 6. Membrane permeabilizing activity of AI-hemocidin 2: (A) the outer membrane permeabilization of $E$. coli by AI-hemocidin 2, NPN uptake (\%) is relative to polymyxin B, a positive control with a strong outer membrane permeabilizing property, ${ }^{* *} p<0.01$; (B) cytoplasmic membrane permeabilization of S. aureus by AI-hemocidin 2; and (C) cytoplasmic membrane permeabilization of E. coli by AI-hemocidin 2. Each assay was performed in triplicate, and the results are presented as the mean $\pm \mathrm{SD}$.

\subsection{Propidium Iodide Uptake Experiment}

Propidium iodide (PI), a DNA dye that passes through damaged cell membranes rather than integrating into the cell membrane, was used as a sensitive indicator to investigate cell membrane integrity and cell death by flow cytometry [50]. In the absence of peptide, the amount of PI uptake in E. coli and S. aureus cells was low, indicating an intact cell membrane. E. coli and S. aureus cells treated with $1 \times$ MIC or $3 \times$ MIC AI-hemocidin 2 displayed distinctly increased levels of PI uptake relative to cells incubated in the absence of AI-hemocidin 2 (Figure 7). A dose-dependent increase in PI fluorescence indicated that AI-hemocidin 2 was capable of damaging the E. coli and $S$. aureus cell membranes. Cell integrity damage assays were carried out concurrently with membrane permeabilization tests of antibacterial agents to establish whether these two effects correlated. For example, the proline-rich peptide Bac7(1-35) rapidly killed E. coli at micromolar concentrations, while PI remained outside the cells [50]. These results indicated that AI-hemocidin 2 was capable of damaging cell integrity and improving the permeability of the cell membrane.

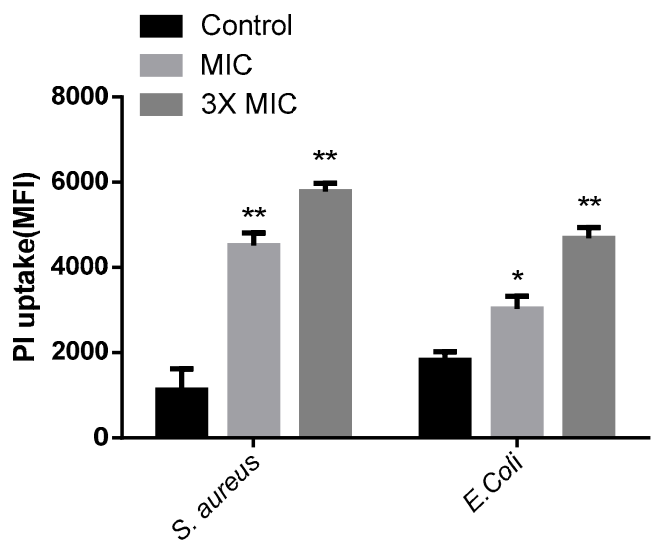

Figure 7. Effects of AI-hemocidin 2 on the membrane integrity of different bacterial strains. The data show the MFI (mean fluorescence intensity). ${ }^{*} p<0.05$ and ${ }^{* *} p<0.01$ versus control, and each assay was performed in triplicate. The results are presented as the mean $\pm \mathrm{SD}$. 


\subsection{Examination of the Morphologic Changes in Cells by Scanning Electron Microscopy}

Direct visualization of AI-hemocidin 2-induced E. coli and S. aureus cellular damage was assessed by scanning electron microscopy (SEM). AI-hemocidin 2 treatment induced cell morphological changes. Compared with the control, $1 \times$ MIC AI-hemocidin 2 treatment for $1 \mathrm{~h}$ induced partial damage of the $S$. aureus membrane, and severe membrane wrinkling and the release of cellular contents occurred within $3 \mathrm{~h}$ of treatment (Figure $8 \mathrm{~A}-\mathrm{C}$ ).
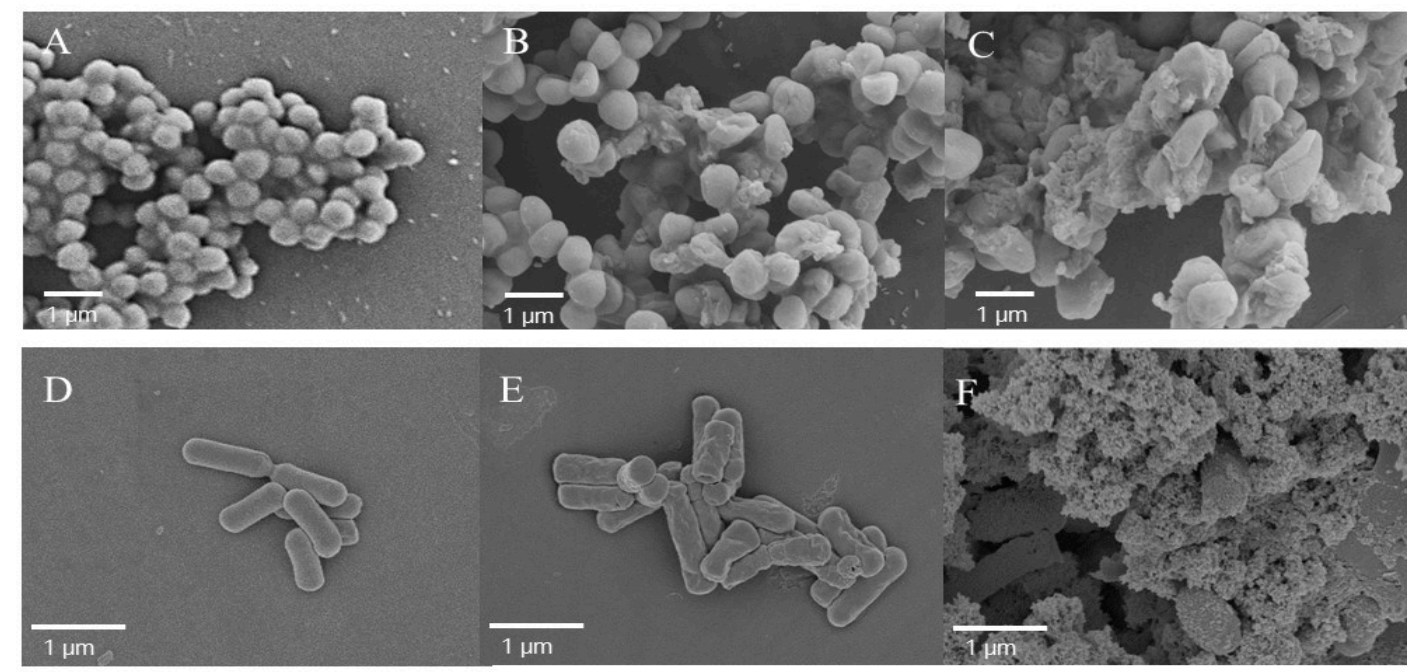

Figure 8. Scanning electron micrographs of S. aureus and E. coli treated with AI-hemocidin 2: (A) control, S. aureus without the peptide; (B) S. aureus treated with AI-hemocidin 2 at $1 \times$ MIC for $1 \mathrm{~h}$; (C) S. aureus treated with AI-hemocidin 2 at $1 \times$ MIC for $3 \mathrm{~h}$; (D) control, E. coli without peptide; (E) E. coli treated with AI-hemocidin 2 at $1 \times$ MIC for $1 \mathrm{~h}$; and (F) E. coli treated with AI-hemocidin at $1 \times$ MIC for $3 \mathrm{~h}$.

The effects of AI-hemocidin 2 on E. coli are shown in Figure 8D-F. A smooth and intact membrane was exhibited in untreated $E$. coli cells. By contrast, membrane surface roughness and corrugation was observed after $1 \mathrm{~h}$ of treatment with $1 \times \mathrm{MIC}$ AI-hemocidin 2 (Figure 8E), and ruptured membranes and leakage of cellular contents were observed following $3 \mathrm{~h}$ of treatment with $1 \times$ MIC AI-hemocidin 2 (Figure 8F). These results suggested that AI-hemocidin 2 is capable of destroying cellular integrity and inducing significant deformation in cellular morphology. The cell surface changes induced by AI-hemocidin 2 were similar to those previously reported [31,51]. Peptides interact with the cellular membrane via binding to negatively charged constituents on the outer membrane, such as lipopolysaccharide (LPS), which is followed by membrane destabilization [52]. In addition, it has previously been proposed that the $\alpha$-helical conformation contributes to the antibacterial activity by disrupting membrane integrity [41].

\section{Materials and Methods}

\subsection{Materials and Strain Culture Conditions}

A. inflata materials were purchased from Chengyang seafood market, Qingdao, China, and were identified by Rongmin Yu (Jinan University, Guangzhou, China). The mantle mass was dissected, weighed and stored at $-20^{\circ} \mathrm{C}$. DEAE Sepharose Fast Flow and SP Sepharose Fast Flow were purchased from GE Healthcare. Tris, SDS, Coomassie brilliant blue R-250, dimethyl sulfoxide (DMSO), PI, NPN, polymyxin B, ONPG, 3-(4,5-dimethyl-2-thiazolyl)-2,5-diphenyl-2H-tetrazolium bromide (MTT), streptomycin, and penicillin were obtained from Sigma Chemical Co. (St. Louis, MO, USA). RPMI-1640, fetal bovine serum (FBS) and LB broth were purchased from GIBCO Invitrogen Corporation (San Diego, 
CA, USA). Ciprofloxacin was purchased from Guangzhou Baiyunshan Pharmaceutical Co., Ltd. (Guangzhou, China). Other commercially available chemicals and reagents were of analytical grade.

Bacteria were grown in LB broth at $37^{\circ} \mathrm{C}$ unless otherwise stated. LB medium was also used for antibacterial activity tests. All bacteria were stored as frozen cultures at $-80^{\circ} \mathrm{C}$ in appropriate culture medium with $30 \%(v / v)$ glycerol.

\subsection{Screening for Antibacterial Activity Components}

To rapidly screen the antimicrobial activity of each purified fraction, the disc diffusion method according to the National Committee for Clinical Laboratory Standards (NCCLS) was applied. E. coli was used as the test microorganism. A total of $10^{6}$ colony-forming units (CFUs) $/ \mathrm{mL}$ of E. coli were poured onto solid LB medium plates. Afterwards, $20 \mu \mathrm{L}$ of sample solutions (concentration of $2.00 \mathrm{mg} / \mathrm{mL})$ was dropped onto sterilized filter paper $(\Phi=6 \mathrm{~mm})$ that had been pasted on the plates. The plates were completely dried before incubated at $37^{\circ} \mathrm{C}$ for $24 \mathrm{~h}$. The antibacterial activities of each purified fraction were determined by measuring the diameter of the inhibition zone with a vernier caliper. The fractions with a relatively large inhibition zone were used in subsequent studies. The experiments were performed in triplicate.

\subsection{Purification of Hemoglobin $\mathrm{Hb}-\mathrm{I}$}

Extraction and separation procedures were performed at $4{ }^{\circ} \mathrm{C}$. A. inflata mantle mass $(200 \mathrm{~g})$ was completely homogenized (10,000 rpm, DS-1, Shanghai Jingke, Shanghai, China) and extracted using phosphate buffer ( $\mathrm{pH} 8.0,30 \mathrm{mM}$ ). The supernatant was precipitated with $70-100 \%$ saturation of solid ammonium sulfate then the precipitate was re-dissolved, dialyzed and lyophilized.

After lyophilization, the sample was applied to a diethyl-aminoethanol (DEAE)-sepharose Fast Flow anion exchange column $(2.5 \times 40 \mathrm{~cm})$ with stepwise elute that had $0,0.1,0.3$ and $2 \mathrm{M} \mathrm{NaCl}$ prepared in $30 \mathrm{mM}$ Tris- $\mathrm{HCl}$ buffer $(\mathrm{pH} 8.0)$ at a flow rate of $1.0 \mathrm{~mL} / \mathrm{min}$. After purification by anion exchange chromatography, the fraction with the highest antibacterial activity was loaded onto a sulfopropyl (SP) Sepharose Fast Flow ion exchange chromatography column $(2.5 \times 40 \mathrm{~cm})$ and stepwise eluted with increasing concentrations of $\mathrm{NaCl}(0,0.5$ and $1 \mathrm{M})$ dissolved in $30 \mathrm{mM}$ phosphate buffer ( $\mathrm{pH}$ 6.0). In each purification step, the elution was monitored at $280 \mathrm{~nm}$ by $\mathrm{UV}$ absorbance. Fractions or individual peaks were collected, dialyzed against distilled water using dialysis tube (MWCO 1000, Qiyun Biotech., Guangzhou, China) and freeze-dried for evaluation of the antibacterial activity.

\subsection{Molecular Mass and Amino Acid Sequence Determination of Hemoglobin Hb-I}

The precise molecular weight of the purified polypeptide was determined with an API type 4000 QTRAP mass spectrometer (Applied Bio system, Foster City, CA, USA), which was operated in positive electrospray ionization (ESI+ve) mode [33]. The gas used for drying (35 psi) and ESI nebulization (45 psi) was high-purity nitrogen. To determine the N-terminal amino acid sequence, the purified polypeptide was applied to a protein sequencer PROCISE 491 (Applied Biosystems, Foster City, CA, USA) and analyzed by Edman degradation according to a reported protocol [33]. The homology search of the N-terminal sequence was performed using BLAST software in NCBI.

\subsection{Bioinformatics Analysis}

Trypsin hydrolysis simulation of Hb-I was analyzed with the ExPASy Bioinformatics Resource Portal (http:/ /www.expasy.org/tools/). Several trypsin-hydrolyzed peptides of $\mathrm{Hb}$-I with potential antibacterial activity (AI-hemocidins) were discovered by screening with the APD database (http://aps.unmc.edu/AP/main.php). The physical and chemical parameters of AI-hemocidins were analyzed through the ExPASy Bioinformatics Resource Portal (http://www.expasy.org/tools/). The helix structures of the peptides were predicted by HeliQuest (http://heliquest.ipmc.cnrs.fr/). 


\subsection{Peptide Synthesis}

AI-hemocidin 1 (PSVQGAAAQLTADVKK), AI-hemocidin 2 (DLRDSWKVIGSDKK), AI-hemocidin 3 (ISAAEFGKINGPIKK) and AI-hemocidin 4 (VLASKNFGDK) were synthesized by GL Biochem Ltd. (Shanghai, China) with solid-phase methods using $\mathrm{N}$-(9-fluorenyl) methoxycarbonyl (Fmoc) chemistry. All peptides were analyzed by HPLC and mass spectrometry to confirm purity higher than $95 \%$.

\subsection{Determination of the Antibacterial Spectrum and Minimum Inhibitory Concentration}

The antibacterial activity of $\mathrm{Hb}-\mathrm{I}$ and AI-hemocidins was determined against both gram-positive and gram-negative bacteria strains, including P. aeruginosa, E. coli, S. aureus, S. epidermidis, B. subtilis and E. faecalis. Clinically isolated P. aeruginosa was provided by the First Affiliated Hospital of Jinan University. MICs of the samples were determined by a modified version of NCCLS broth microdilution method as reference [53]. The bacterial strains were inoculated and grown to mid-log phase in LB broth at $37^{\circ} \mathrm{C}$. Samples prepared in $0.9 \%$ sodium chloride solution were prepared in different concentrations with 2-fold serial dilution, from 0.5 to $1600 \mu \mathrm{g} / \mathrm{mL}$. Ciprofloxacin was used as a control. A mixture of $90 \mu \mathrm{L}$ of LB broth, $100 \mu \mathrm{L}$ of inoculum suspension $\left(1 \times 10^{6} \mathrm{CFU} / \mathrm{mL}\right)$, and $10 \mu \mathrm{L}$ of series concentrations for each sample was placed in sterile 96 -well plates and incubated at $37^{\circ} \mathrm{C}$ for $18 \mathrm{~h}$. The absorbance at $600 \mathrm{~nm}$ was recorded with a microplate reader. The MIC was defined as the lowest concentration of the tested sample that completely prevented bacterial growth.

\subsection{Hemolytic Assay and Cell Viability}

Murine blood with citric acid treatment was centrifuged at $3000 \times g$ for $5 \mathrm{~min}$, and the plasma and buffy coat were removed. Erythrocytes were washed three times with $0.9 \%$ saline solution and then re-suspended to $10 \mathrm{mM} \mathrm{PB} \mathrm{(pH} \mathrm{7.4)} \mathrm{containing} 150 \mathrm{mM} \mathrm{NaCl}$. Red blood cells were then treated with serial dilutions of the peptide samples in a 96-well plate at $37^{\circ} \mathrm{C}$ for $60 \mathrm{~min}$. Control samples included a saline solution and 1\% Triton X-100 for 0 and 100\% hemolysis, respectively. Hemolysis was expressed as the hemoglobin content obtained from the absorbance of the supernatant at $570 \mathrm{~nm}$ after centrifugation at $3000 \times g$ for $5 \mathrm{~min}[53,54]$. The hemolysis assay was performed in triplicate.

Human HEK293 embryonic kidney cells $\left(1 \times 10^{5}\right.$ cells $\left./ \mathrm{mL}\right)$ were incubated in 96-well plates using Dulbecco's modified Eagle's medium (DMEM) that contained $10 \%$ fetal calf serum, penicillin $(100 \mathrm{U} / \mathrm{mL})$ and streptomycin $(100 \mu \mathrm{g} / \mathrm{mL})$ at $37^{\circ} \mathrm{C}$ in a humidified incubator with $5 \% \mathrm{CO}_{2}$ atmosphere. Cell viability was evaluated by conventional MTT reduction assays [53]. The absorbance at $570 \mathrm{~nm}$ of the resulting solution was measured with a microplate reader (Synergy 2, Biotech, VT, USA). The experiments were performed in triplicate.

\subsection{Effects of $\mathrm{pH}$ and Temperature on the Antibacterial Activity}

To investigate the effects of the temperature and $\mathrm{pH}$ on the antimicrobial activities of AI-hemocidin 2, the disc diffusion method was applied against $S$. aureus, P. aeruginosa and E. coli [55]. Samples were incubated with the following solutions: $0.01 \% \mathrm{NaOH}(\mathrm{pH} 10), 0.01 \% \mathrm{HAc}(\mathrm{pH} 3)$ and sterile water ( $\mathrm{pH} 7$ ). After $1 \mathrm{~h}$ of incubation in the appropriate solution, the sample solutions were determined using the microdilution method. To determine the thermal stability, samples were incubated at $100^{\circ} \mathrm{C}$ for $10 \mathrm{~min}$. Then, the samples were cooled and used for determination. Each assay was performed in triplicate.

\subsection{Membrane Permeability Assay}

To assess the cell membrane permeability ability of AI-hemocidin 2, the membrane permeability assay was applied with E. coli and S. aureus. The outer membrane permeability assay for E. coli was performed using NPN uptake assay [56]. E. coli were cultured to the logarithmic phase in LB broth at $37{ }^{\circ} \mathrm{C}$ and adjusted to an $\mathrm{OD}_{600}$ of 0.5 . Cells were washed 3 times and re-suspended with $5 \mathrm{mM}$ HEPES buffer ( $\mathrm{pH}$ 7.2). NPN was added to $1 \mathrm{~mL}$ of cells in a quartz cuvette with a final 
concentration of $10 \mu \mathrm{M}$. After $180 \mathrm{~s}$, the peptide samples at their $1 \times$ MIC and $3 \times$ MIC were added to the cuvette. The fluorescence increase by partitioning NPN into the outer membrane was measured using a fluorescence spectrometer (HITACHI F-4500, HITACHI, Tokyo, Japan) until there was no further increase in fluorescence. The values were recorded at $360 \mathrm{~s}$ after sample treatment. The outer membrane permeability was evaluated by the \% NPN uptake.

$$
\% \text { NPN uptake }=(\text { Fobs }- \text { F0) } /(\text { F100 }- \text { F0 }) \times 100
$$

where Fobs is the observed fluorescence at a given peptide concentration, F0 is the initial fluorescence of NPN with bacteria in the absence of peptide, and F100 is the fluorescence of NPN with bacteria cells upon the addition of $10 \mu \mathrm{g} / \mathrm{mL}$ Polymyxin $\mathrm{B}$, a positive control with a strong outer membrane permeabilizing property.

The permeabilities of the E. coli inner cell membrane and S. aureus cell membrane were assessed by detection of ONPG as a substrate accounting for its non-membrane permeation. E. coli and S. aureus were incubated to the mid-log phase, washed, and re-suspended in $10 \mathrm{mM} \mathrm{PBS} \mathrm{(pH} \mathrm{7.4)} \mathrm{[57].}$ ONPG $(1.5 \mathrm{mM})$ was dissolved in the same buffer, and peptide samples at their $1 \times$ MIC and $3 \times$ MIC were incubated with microbial cells. The hydrolysis of ONPG to o-nitrophenol was monitored at $405 \mathrm{~nm}$ every $30 \mathrm{~min}$ using a microplate reader. A cell suspension without sample was used as a control.

\subsection{Integrity of the Bacterial Membrane}

The bacterial membrane integrity was evaluated by determining the uptake of PI using BD Accuri C6 flow cytometry (Ann Arbor, MI, USA) [58]. Tested bacterial strains (E. coli and S. aureus) were incubated to mid-log phase in LB broth at $37^{\circ} \mathrm{C}$. The density of the bacterial suspensions was adjusted to $1 \times 10^{6} \mathrm{CFU} / \mathrm{mL}$ by dilution in LB broth containing AI-hemocidin 1 and AI-hemocidin 2 . The bacterial suspension was incubated at $37^{\circ} \mathrm{C}$ for $60 \mathrm{~min}$ with different samples at the MIC or $3 \times$ MIC. PBS (10 Mm, pH 7.4) was used as a negative control. Afterwards, sample-treated bacteria were washed twice and re-suspended with PBS. Then, the suspensions were incubated with PI $(100 \mu \mathrm{M})$ for $10 \mathrm{~min}$ in an ice bath. In flow cytometry, 40,000 events were collected for each sample at the medium flow rate with an excitation and emission at 488 and $525 \mathrm{~nm}$, respectively.

\subsection{Examination of Bacterial Membrane Damage by SEM}

E. coli, and S. aureus were cultured to the logarithmic phase in LB broth and then harvested by centrifugation at $1000 \times g$ for $10 \mathrm{~min}$. The cells were washed 3 times with $10 \mathrm{mM} \mathrm{PBS} \mathrm{(pH} \mathrm{7.4)} \mathrm{and}$ re-suspended to an $\mathrm{OD}_{600}$ of 0.2 . Thereafter, the bacterial suspension was incubated at $37^{\circ} \mathrm{C}$ for 1 or $3 \mathrm{~h}$ with different samples at $1 \times$ MIC. Following incubation, the cells were collected and washed 3 times with $10 \mathrm{mM}$ PBS at $3000 \times g$ for $5 \mathrm{~min}$. Bacterial cell pellets were then fixed overnight with $2.5 \%$ $(v / v)$ glutaraldehyde in PBS at $4{ }^{\circ} \mathrm{C}$ and then washed twice with PBS. Afterwards, the cell pellets were dehydrated in a graded ethanol series $(50,60,70,80,90$ and 100\%) for $10 \mathrm{~min}$ each. The dried samples were transferred to a mixture $(1: 1, v / v)$ of ethanol and isoamyl acetate for $20 \mathrm{~min}$. The specimens were dried using a critical point dryer that was coated with gold. The cell morphology was observed under a field emission SEM (Carl Zeiss Ultra 55, Oberkochen, Germany) [44].

\subsection{Determination and Secondary Structure Prediction}

The secondary structures of AI-hemocidin 2 in mimicking aqueous environment and mimicking the hydrophobic environment of the microbial membrane conditions were measured using a J-820 spectropolarimeter (Jasco, Tokyo, Japan) [43]. The spectra were recorded at a scanning speed of $10 \mathrm{~nm} / \mathrm{min}$ at wavelengths range from 195 to $250 \mathrm{~nm}$ in $10 \mathrm{mM}$ PBS and 50\% TFE. All procedures were performed at $25{ }^{\circ} \mathrm{C}$, and an average of three scans was collected for each sample. The final sample concentration was $150 \mu \mathrm{M}$. The secondary structure of AI-hemocidin 2 was built by homology modeling using the I-TASSER server (http:/ / zhanglab.ccmb.med.umich.edu/I-TASSER/). 


\subsection{Statistical Analysis}

The software package SPSS Statistics 20.0 (SPSS Inc., Chicago IL, USA) for Windows was used for statistical analysis and GraphPad Prism 5.0 (GraphPad Software, San Diego, CA, USA) was used for the presentation of data. The experimental data are presented as the mean \pm standard deviation (SD) unless otherwise indicated. SPSS Statistics was used to calculate values according to one way analysis of variance (ANOVA) followed by Duncan's multiple range tests. The independent two-sample Student's t-test was used to establish significant differences in the experiment of the outer membrane permeabilization of E. coli by AI-hemocidin 2. $p$ values of less 0.05 were considered to be significantly different.

\section{Conclusions}

In this study, an antibacterial hemoglobin subunit $\mathrm{Hb}-\mathrm{I}$ was purified from the mantle mass of A. inflata. A novel N-terminal peptide of hemoglobin, AI-hemocidin 2, was identified from $\mathrm{Hb}-\mathrm{I}$ by bioinformatic analysis. AI-hemocidin 2 exhibited broad-spectrum antibacterial effects against Gram-negative and Gram-positive bacteria and showed a typical $\alpha$-helical structure in the membrane mimetic environment. AI-hemocidin 2 also displayed low hydrolysis activity and cytotoxicity with bacterial selectivity. The results of membrane permeabilization, flow cytometry and SEM assays demonstrated that one of the mechanisms of AI-hemocidin 2-induced cell death might be to disrupt the bacterial membrane. These findings revealed that AI-hemocidin 2 might be an attractive and promising candidate as a nature-derived antibacterial agent against pathogenic bacteria. In addition, exploring the peptide fragments of hemoglobin by employing bioinformatic analysis is a feasible approach for identifying antibacterial peptides.

Supplementary Materials: The following are available online at www.mdpi.com/1660-3397/15/7/205/s1, Figure S1: Purity confirmation of J1S1. (A) The result of Tricine-SDS-PAGE; (B) The result of Native PAGE.; Figure S2: The result of n-terminal amino acid sequencing of $\mathrm{Hb}-\mathrm{I}$.

Acknowledgments: This study was financially supported by National Natural Science Foundation of China (No. 81374015 and 81503303), Major Science and Technology Projects/Significant New Drugs Creation of Guangdong Province (No. 2013A022100032), and Ocean and Fisheries Science and Technology Development Projects of Guangdong Province (No. A201501C04). The authors thank Dongbo Yu of The University of Chicago, Illinois, USA, for proofreading our manuscript.

Author Contributions: Chunlei Li, Jianhua Zhu and Rongmin Yu conceived and designed the experiments; Chunlei Li, Jianhua Zhu, Yanqing Wang, Yuyan Chen, Weiming Zheng and Jinging Li performed the experiments; Chunlei Li, Jianhua Zhu, Liyan Song and Rongmin Yu analyzed the data; and Chunlei Li, Jianhua Zhu, Liyan Song and Rongmin Yu wrote the paper.

Conflicts of Interest: The authors declare no conflict of interest.

\section{References}

1. Centers for Disease Control and Prevention, Office of Infectious Disease. Antibiotic Resistance Threats in the United States. Available online: http:/ / www.cdc.gov/drugresistance/threat-report-2013 (accessed on 12 April 2013).

2. Golkar, Z.; Bagasra, O.; Pace, D.G. Bacteriophage therapy: A potential solution for the antibiotic resistance crisis. J. Infect. Dev. Ctries. 2014, 8, 129-136. [PubMed]

3. Gould, I.M.; Bal, A.M. New antibiotic agents in the pipeline and how they can help overcome microbial resistance. Virulence 2013, 4, 185-191. [PubMed]

4. Congressional Research Service Report. Life Expectancy in the United States. Available online: http:/ / www.menshealthnetwork.org/library/CRSlifeexpectRL32792.pdf (accessed on 12 April 2017).

5. Sengupta, S.; Chattopadhyay, M.K.; Grossart, H.P. The multifaceted roles of antibiotics and antibiotic resistance in nature. Front. Microbiol. 2013, 4, 1-13.

6. Wright, G.D. Something old, something new: Revisiting natural products in antibiotic drug discovery. Can. J. Microbiol. 2014, 60, 147-154. [PubMed] 
7. Brogan, D.M.; Mossialos, E. A critical analysis of the review on antimicrobial resistance report and the infectious disease financing facility. Glob. Health 2016, 12, 1-7.

8. $\quad$ Lin, M.C.; Lin, S.B.; Lee, S.C.; Lin, C.C.; Hui, C.F.; Chen, J.Y. Antimicrobial peptide of an anti-lipopolysaccharide factor modulates of the inflammatory response in raw264.7 cells. Peptides 2010, 31, 1262-1272. [PubMed]

9. Stark, M.; Liu, L.P.; Deber, C.M. Cationic hydrophobic peptides with antimicrobial activity. Antimicrob. Agents Chemother. 2002, 46, 3585-3590. [PubMed]

10. Van 't Hof, W.; Veerman, E.C.I.; Helmerhorst, E.J.; Amerongen, A.V.N. Antimicrobial peptides properties and applicability. Biol. Chem. 2001, 382, 597-619. [PubMed]

11. Izadpanah, A.; Gallo, R.L. Antimicrobial peptides. J. Am. Acad. Dermatol. 2005, 52, 381-390. [PubMed]

12. Wimley, W.C. Describing the mechanism of antimicrobial peptide action with the interfacial activity model. ACS Chem. Biol. 2010, 5, 905-917. [CrossRef] [PubMed]

13. Zasloff, M. Antimicrobial peptides of multicellular organisms. Nature 2002, 415, 389-395. [CrossRef] [PubMed]

14. Aneiros, A.; Garateix, A. Bioactive peptides from marine sources: Pharmacological properties and isolation procedures. J. Chromatogr. B Anal. Technol. Biomed. Life Sci. 2004, 803, 41-53. [CrossRef] [PubMed]

15. Harnedy, P.A.; FitzGerald, J.F. Bioactive peptides from marine processing waste and shellfish: A review. J. Funct. Foods 2012, 4, 6-24. [CrossRef]

16. Nam, B.H.; Moon, J.Y.; Park, E.H.; Kong, H.J.; Kim, Y.O.; Kim, D.G.; Kim, W.J.; An, C.M.; Seo, J.K. Antimicrobial and antitumor activities of novel peptides derived from the lipopolysaccharide- and-1,3-glucan binding protein of the pacific abalone haliotis discus hannai. Mar. Drugs 2016, 14, 227. [CrossRef] [PubMed]

17. Simon-Colin, C.; Gueguen, Y.; Bachere, E.; Kouzayha, A.; Saulnier, D.; Gayet, N.; Guezennec, J. Use of natural antimicrobial peptides and bacterial biopolymers for cultured pearl production. Mar. Drugs 2015, 13, 3732-3744. [CrossRef] [PubMed]

18. Parish, C.A.; Jiang, H.; Tokiwa, Y.; Berova, N.; Nakanishi, K.; McCabe, D.; Zuckerman, W.; Xia, M.M.; Gabay, J.E. Broad-spectrum antimicrobial activity of hemoglobin. Bioorgan. Med. Chem. 2001, 9, 377-382. [CrossRef]

19. Ivanov, V.T.; Karelin, A.A.; Philippova, M.M.; Nazimov, I.V.; Pletnev, V.Z. Hemoglobin as a source of endogenous bioactive peptides: The concept of tissue-specific peptide pool. Biopolymers 1997, 43, 171-188. [CrossRef]

20. Ullal, A.J.; Litaker, R.W.; Noga, E.J. Antimicrobial peptides derived from hemoglobin are expressed in epithelium of channel catfish (ictalurus punctatus, rafinesque). Dev. Comp. Immunol. 2008, 32, 1301-1312. [CrossRef] [PubMed]

21. Fogaca, A.C.; da Silva, P.I.J.; Miranda, M.T.; Bianchi, A.G.; Miranda, A.; Ribolla, P.E.; Daffre, S. Antimicrobial activity of a bovine hemoglobin fragment in the tick boophilus microplus. J. Biol. Chem. 1999, 274, 25330-25334. [CrossRef] [PubMed]

22. Liepke, C.; Baxmann, S.; Heine, C.; Breithaupt, N.; Ständker, L.; Forssmann, W.G. Human hemoglobin-derived peptides exhibit antimicrobial activity: A class of host defense peptides. J. Chromatogr. B 2003, 791, 345-356. [CrossRef]

23. Catiau, L.; Traisnel, J.; Chihib, N.E.; Le Flem, G.; Blanpain, A.; Melnyk, O.; Guillochon, D.; Nedjar-Arroume, N.R. A minimal peptidic sequence obtained from beta-chain hemoglobin exhibiting an antimicrobial activity. Peptides 2011, 32, 1463-1468. [CrossRef] [PubMed]

24. Mak, P.; Wojcik, K.; Wicherek, L.; Suder, P.; Dubin, A. Antibacterial hemoglobin peptides in human menstrual blood. Peptides 2004, 25, 1839-1847. [CrossRef] [PubMed]

25. Zhang, Q.H.; Xu, Y.Z.; Wang, Q.; Hang, B.L.; Sun, Y.W.; Wei, X.X.; Hu, J.H. Potential of novel antimicrobial peptide $\mathrm{p} 3$ from bovine erythrocytes and its analogs to disrupt bacterial membranes in vitro and display activity against drug-resistant bacteria in a mouse model. Antimicrob. Agents Chemother. 2015, 59, 2835-2841. [CrossRef] [PubMed]

26. Catiau, L.; Traisnel, J.; Delval-Dubois, V.; Chihib, N.E.; Guillochon, D.; Nedjar-Arroume, N. Minimal antimicrobial peptidic sequence from hemoglobin alpha-chain: Kyr. Peptides 2011, 32, 633-638. [CrossRef] [PubMed]

27. Coates, C.J.; Decker, H. Immunological properties of oxygen-transport proteins: Hemoglobin, hemocyanin and hemerythrin. Cell. Mol. Life Sci. 2017, 74, 293-317. [CrossRef] [PubMed] 
28. Zhuang, J.; Coates, C.J.; Zhu, H.; Zhu, P.; Wu, Z.; Xie, L. Identification of candidate antimicrobial peptides derived from abalone hemocyanin. Dev. Comp. Immunol. 2015, 49, 96-102. [CrossRef] [PubMed]

29. Xu, J.; Chen, Z.; Song, L.; Chen, L.; Zhu, J.; Lv, S.; Yu, R. A new in vitro anti-tumor polypeptide isolated from Arca inflata. Mar. Drugs 2013, 11, 4773-4787. [CrossRef] [PubMed]

30. Rowley, A.F.; Powell, A. Invertebrate immune systems-specific, quasi-specific, or nonspecific? J. Immunol. 2007, 179, 7209-7214. [CrossRef] [PubMed]

31. Mine, Y.; Ma, F.P.; Lauriau, S. Antimicrobial peptides released by enzymatic hydrolysis of hen egg white lysozyme. J. Agric. Food Chem. 2004, 52, 1088-1094. [CrossRef] [PubMed]

32. Rastogi, N.N.; Alam, H.; Pandey, S.; Gautam, L.; Sinha, M.; Shin, K.; Manzoor, N.; Virdi, J.S.; Kaur, P.; Sharma1, S.; et al. Preparation and antimicrobial action of three tryptic digested functional molecules of bovine lactoferrin. PLoS ONE 2014, 9, e90011. [CrossRef] [PubMed]

33. Chen, Y.; Li, C.; Zhu, J.; Xie, W.; Hu, X.; Song, L.; Zi, J.; Yu, R. Purification and characterization of an antibacterial and anti-inflammatory polypeptide from arca subcrenata. Int. J. Biol. Macromol. 2017, 96, 177-184. [CrossRef] [PubMed]

34. Hu, M.; Zhao, H.; Zhang, C.; Yu, J.; Lu, Z. Purification and characterization of plantaricin 163, a novel bacteriocin produced by Lactobacillus plantarum 163 isolated from traditional Chinese fermented vegetables. J. Agric. Food Chem. 2013, 61, 11676-11682. [CrossRef] [PubMed]

35. Hata, T.; Tanaka, R.; Ohmomo, S. Isolation and characterization of plantaricin ASM1: A new bacteriocin produced by Lactobacillus plantarum A-1. Int. J. Food Microbiol. 2010, 137, 94-99. [CrossRef] [PubMed]

36. Jiang, J.; Shi, B.; Zhu, D.; Cai, Q.; Chen, Y.; Li, J.; Qi, K.; Zhang, M. Characterization of a novel bacteriocin produced by Lactobacillus sakei LSJ618 isolated from traditional Chinese fermented radish. Food Control 2012, 23, 338-344. [CrossRef]

37. Pitout, J.D. Extraintestinal pathogenic Escherichia coli: An update on antimicrobial resistance, laboratory diagnosis and treatment. Expert Rev. Anti-Infect. Ther. 2012, 10, 1165-1176. [CrossRef] [PubMed]

38. Froidevaux, R.; Krier, F.; Nedjar-Arroume, N.; Vercaigne-Marko, D.; Kosciarz, E.; Ruckebusch, C.; Dhulster, P.; Guillochon, D. Antibacterial activity of a pepsin-derived bovine hemoglobin fragment. FEBS Lett. 2001, 491, 159-163. [CrossRef]

39. Pakdeesuwan, A.; Araki, T.; Daduang, S.; Payoungkiattikun, W.; Jangpromma, N.; Klaynongsruang, S. In vivo wound healing activity of crocodile (crocodylus siamensis) hemoglobin and evaluation of antibacterial and antioxidant properties of hemoglobin and hemoglobin hydrolysate. J. Microbiol. Biotechnol. 2016, 27, 26-35. [CrossRef] [PubMed]

40. Friedrich, C.L.; Rozek, A.; Patrzykat, A.; Hancock, R.E.W. Structure and mechanism of action of an indolicidin peptide derivative with improved activity against gram-positive bacteria. J. Biol. Chem. 2001, 276, 24015-24022. [CrossRef] [PubMed]

41. Jenssen, H.; Hamill, P.; Hancock, R.E.W. Peptide antimicrobial agents. Clin. Microbiol. Rev. 2006, $19,21$. [CrossRef] [PubMed]

42. Dathe, M.; Wieprecht, T. Structural features of helical antimicrobial peptides: Their potential to modulate activity on model membranes and biological cells. Biochim. Biophys. Acta 1999, 1462, 71-87. [CrossRef]

43. Lopez-Abarrategui, C.; McBeth, C.; Mandal, S.M.; Sun, Z.J.; Heffron, G.; Alba-Menendez, A.; Migliolo, L.; Reyes-Acosta, O.; Garcia-Villarino, M.; Nolasco, D.O.; et al. Cm-p5: An antifungal hydrophilic peptide derived from the coastal mollusk cenchritis muricatus (gastropoda: Littorinidae). FASEB J. 2015, 29, 3315-3325. [CrossRef] [PubMed]

44. Lyu, Y.; Yang, Y.; Lyu, X.; Dong, N.; Shan, A. Antimicrobial activity, improved cell selectivity and mode of action of short pmap-36-derived peptides against bacteria and candida. Sci. Rep. 2016, 6, e27258. [CrossRef] [PubMed]

45. Seo, J.K.; Lee, M.J.; Jung, H.G.; Go, H.J.; Kim, Y.J.; Park, N.G. Antimicrobial function of SHbetaAP, a novel hemoglobin beta chain-related antimicrobial peptide, isolated from the liver of skipjack tuna, katsuwonus pelamis. Fish Shellfish Immunol. 2014, 37, 173-183. [CrossRef] [PubMed]

46. Jeong, M.; Jeon, D.; Shin, A.; Jin, S.; Shin, S.; Park, Y.; Kim, Y. Effects of Hydrophobic Peptoid Substitutions on the Bacterial Cell Selectivity and Antimicrobial Activity of Piscidin 1. Bull. Korean Chem. Soc. 2016, 37, 1545-1551. [CrossRef] 
47. Lee, E.; Shin, A.; Jeong, K.W.; Jin, B.; Jnawali, H.N.; Shin, S.; Shin, S.Y.; Kim, Y. Role of phenylalanine and valine (10) residues in the antimicrobial activity and cytotoxicity of piscidin-1. PLoS ONE 2014, 9, e114453. [CrossRef] [PubMed]

48. Phadke, S.M.; Lazarevic, V.; Bahr, C.C.; Islam, K.; Stolz, D.B.; Watkins, S.; Tencza, S.B.; Vogel, H.J.; Montelaro, R.C.; Mietzner, T.A. Lentivirus lytic peptide 1 perturbs both outer and inner membranes of serratia marcescens. Antimicrob. Agents Chemother. 2002, 46, 2041-2045. [CrossRef] [PubMed]

49. Skerlavaj, B.; Romeo, D.; Gennaro, R. Rapid membrane permeabilization and inhibition of vital functions of gram-negative bacteria by bactenecins. Infect. Immun. 1990, 58, 3724-3730. [PubMed]

50. Scocchi, M.; Mardirossian, M.; Runti, G.; Benincasa, M. Non-membrane permeabilizing modes of action of antimicrobial peptides on bacteria. Curr. Top. Med. Chem. 2016, 16, 76-88. [CrossRef] [PubMed]

51. Lee, N.K.; Han, E.J.; Han, K.J.; Paik, H.D. Antimicrobial effect of bacteriocin ku24 produced by lactococcus lactis ku24 against methicillin-resistant Staphylococcus aureus. J. Food Sci. 2013, 78, 465-469. [CrossRef] [PubMed]

52. Piers, K.L.; Brown, M.H.; Hancock, R.E. Improvement of outer membrane-permeabilizing and lipopolysaccharide-binding activities of an antimicrobial cationic peptide by c-terminal modification. Antimicrob. Agents Chemother. 1994, 38, 2311-2316. [CrossRef] [PubMed]

53. Jin, L.; Bai, X.; Luan, N.; Yao, H.; Zhang, Z.; Liu, W.; Chen, Y.; Yan, X.; Rong, M.; Lai, R. A designed tryptophanand lysine/arginine-rich antimicrobial peptide with therapeutic potential for clinical antibiotic-resistant candida albicans vaginitis. J. Med. Chem. 2016, 59, 1791-1799. [CrossRef] [PubMed]

54. Fernandez-Lopez, S.; Choi, E.C.; Delgado, M.; Granja, J.R.; Khasanov, A.; Kraehenbuehl, K.; Long, G.; Weinberger, D.A.; Wilcoxen, K.M.; Ghadiri, M.R. Antibacterial agents based on the cyclic d,l-alpha-peptide architecture. Nature 2001, 412, 452-455. [CrossRef] [PubMed]

55. Adje, E.Y.; Balti, R.; Kouach, M.; Dhulster, P.; Guillochon, D.; Nedjar-Arroume, N. Obtaining antimicrobial peptides by controlled peptic hydrolysis of bovine hemoglobin. Int. J. Biol. Macromol. 2011, 49, 143-153. [CrossRef] [PubMed]

56. Lv, Y.; Wang, J.; Gao, H.; Wang, Z.; Dong, N.; Ma, Q.; Shan, A. Antimicrobial properties and membrane-active mechanism of a potential alpha-helical antimicrobial derived from cathelicidin pmap-36. PLoS ONE 2014, 9, e86364.

57. Miao, J.; Guo, H.; Chen, F.; Zhao, L.; He, L.; Ou, Y.; Huang, M.; Zhang, Y.; Guo, B.; Cao, Y. Antibacterial effects of a cell-penetrating peptide isolated from kefir. J. Agric. Food Chem. 2016, 64, 3234-3242. [CrossRef] [PubMed]

58. Schaller, A.; Sun, Z.H.; Yang, Y.P.; Somoskovi, A.; Zhang, Y. Salicylate reduces susceptibility of mycobacterium tuberculosis to multiple antituberculosis drugs. Antimicrob. Agents Chemother. 2002, 46, 2636-2639. [CrossRef] [PubMed]

(c) 2017 by the authors. Licensee MDPI, Basel, Switzerland. This article is an open access article distributed under the terms and conditions of the Creative Commons Attribution (CC BY) license (http:/ / creativecommons.org/licenses/by/4.0/). 